\title{
ADENOID CYSTIC CARCINOMA OF DISTAL TRACHEA: A CASE REPORT
}

\author{
Željko Djaković, Zoran Janevski, Vedran Cesarec, \\ Zoran Slobodnjak and Dinko Stančić-Rokotov
}

Jordanovac Department of Thoracic Surgery, Zagreb University Hospital Centre, Zagreb, Croatia

\begin{abstract}
SUMMARY - Primary malignant tumors of the trachea are very rare with the incidence of less than two per million people per year, and only ten percent of them are adenoid cystic carcinomas. Eighty percent of all tracheal tumors are malignant. Diagnosis is usually late because the symptoms mimic other conditions such as asthma. Clinical picture may sometimes be dramatic when airway is almost closed and emergency recanalization is necessary. Diagnosis is made by chest computed tomography scan or magnetic resonance imaging. Definitive treatment is surgical resection alone or followed by radiation therapy or radiation therapy alone. Radical resection is only accomplished in about half of all cases because of the submucosal tumor growth and limited length of tracheal resection. The role of adjuvant radiation therapy in negative resection margin cases is not clear but all patients with positive resection margin benefit from radiation therapy. We present a case of a 43-year-old patient with primary adenoid cystic carcinoma of distal trachea treated by emergency bronchoscopic recanalization and resection of the tracheal tumor with end-to-end anastomosis.
\end{abstract}

Key words: Carcinoma, adenoid cystic; Radiotherapy, adjuvant; Tracheal neoplasms

\section{Introduction}

Primary malignant tumors of the trachea are very rare with the incidence of less than two per million people per year and they account for less than one percent of all malignant tumors ${ }^{1,2}$. Eighty percent of all tracheal tumors are malignant ${ }^{2}$. Most common are squamous cell carcinoma (SCC) and adenoid cystic carcinoma $(\mathrm{ACC})^{1,2}$. While SCC is usually located in the distal part, ACC is usually located in the proximal part of the trachea ${ }^{1}$. ACC grows slowly and clinical course is long. It metastasizes to distant sites and can recur after a long interval. Treatment of choice is surgical resection. If the tumor is too large for resection or unresectable due to invasion of adjacent organs, radio-

Correspondence to: Željko Djaković, MD, Jordanovac Department of Thoracic Surgery, Zagreb University Hospital Centre, Jordanovac 104, HR-10000 Zagreb, Croatia

E-mail: zeljkodjakovic@yahoo.com

Received November 12, 2015, accepted February 3, 2017 therapy is used ${ }^{1-7}$. We present a case of a 43-year-old male patient, member of the cruise ship staff. He was hospitalized for severe stridor and dyspnea and diagnosed with distal tracheal tumor that was not SCC but ACC. This is a rare presentation of this type of tumor and any report of ACC is valuable for data accumulation. This case is specific for unusual localization in distal trachea.

\section{Case Report}

A 43-year-old patient with dyspnea and severe stridor was hospitalized in a general hospital. Computed tomography (CT) scan of the chest revealed distal tracheal tumor almost obstructing complete lumen of distal trachea (Figs. 1 and 2). The patient was intubated and transferred to our hospital. After bronchoscopic assessment, an intervention was performed. About half of the tumor volume was removed by bronchoscopic excision. Tracheal lumen was re-established 


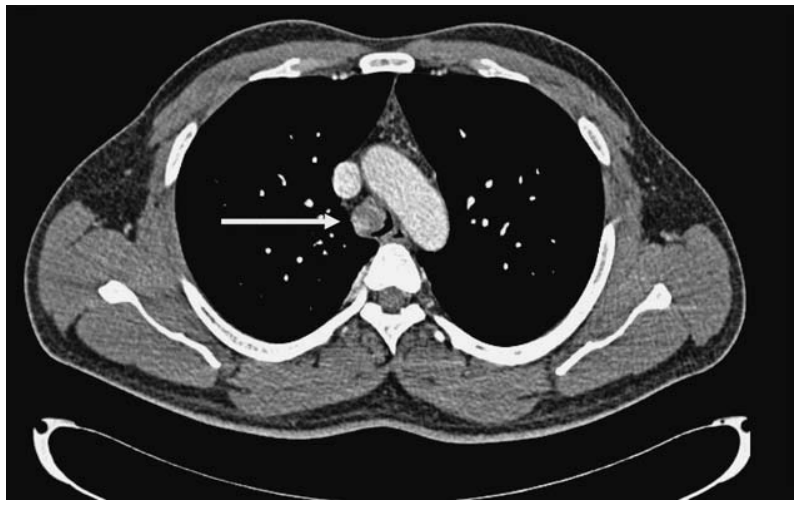

Fig. 1. Chest CT scan showing tumor in distal trachea with barely patent lumen (arrow) - axial view.

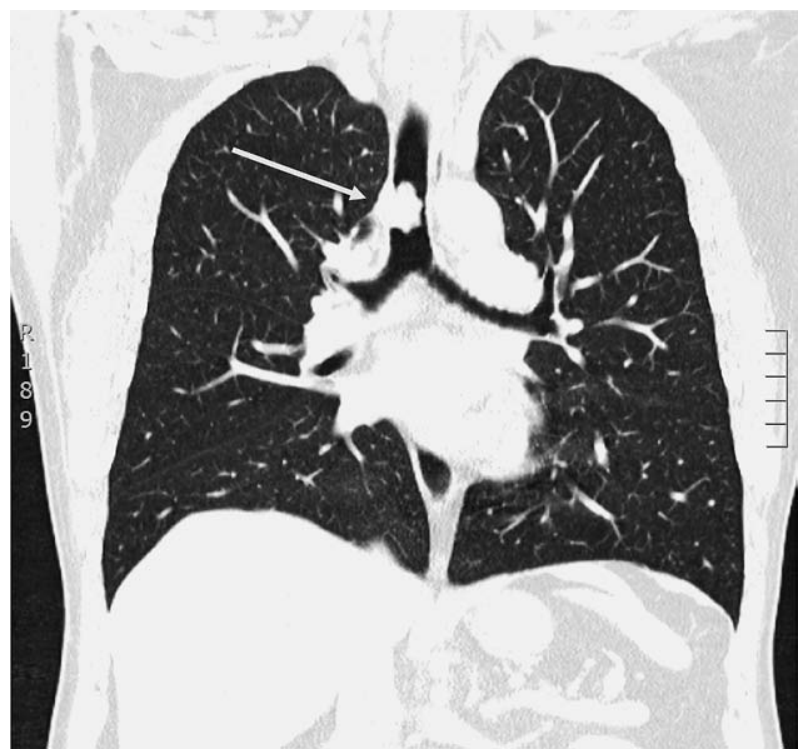

Fig. 2. Chest CT scan showing tumor in distal trachea with barely patent lumen (arrow) - coronal view.

by photocoagulation and additional dilatation. Precisely determined localization after bronchoscopic intervention revealed a tumor one centimeter proximally to the carina infiltrating anterior wall of the trachea by about three centimeters in length. Histopathology confirmed primary ACC. Three days after tracheal recanalization, right thoracotomy, resection of the affected part of the trachea and mediastinal lymphadenectomy was performed. The supracarinal segment of the trachea was resected and end-to-end anastomosis created. Histopathology revealed submucosal spread of the tumor with a positive margin. Anastomosis healed well and follow up bronchoscopy status was satisfactory (Fig. 3). The patient had no respiratory problems.

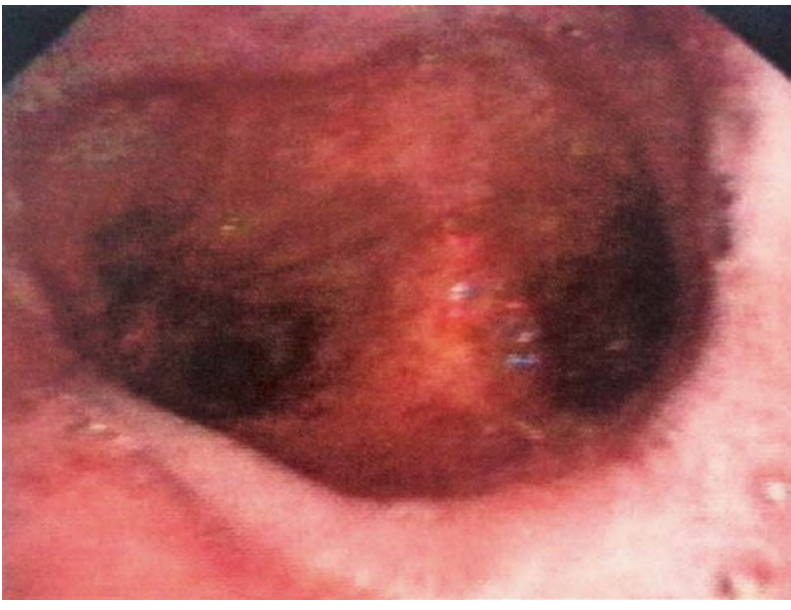

Fig. 3. Bronchoscopy showing precarinal anastomosis with both main bronchi.

He was discharged on postoperative day 8. Adjuvant radiation therapy was recommended.

\section{Discussion}

Primary ACC, previously also called cylindroma, is a rare tumor ${ }^{1,2}$. Only two cases of tracheal tumors per million people per year are recorded, with ACC accounting for about ten percent of these ${ }^{8}$. Both sexes are affected equally in the fifth decade of life. It is not a smoking related condition'. Usual symptoms are cough, wheezing and dyspnea, and patients are often treated for asthma before reaching an accurate diagno$\operatorname{sis}^{2,3}$. This tumor does not have a capsule and spreads directly by submucosal or perineural invasion. More than half of these patients have metastatic disease by hematogenous spread ${ }^{2}$. Lung is the most common site of metastases. Other affected organs are brain, liver, kidney, skin and bone ${ }^{7,10}$. Typical presentation is intraluminal mass on chest CT scan, which infiltrates tracheal wall and obstructs airway.

Treatment includes surgery, radiation therapy, or a combination of both. If possible, resection with endto-end anastomosis should be performed. It is the best option for localized lesion. The nature of spread is the most important reason for incomplete resection ${ }^{11}$. The rates of reported complete resections are around fifty percent $t^{1,8}$. In this case, adjuvant radiation therapy is mandatory ${ }^{1,5,9}$. There are controversies about adjuvant radiation therapy in clear margin cases and local versus systemic radiation therapy ${ }^{1,4,9}$. In our case, we recom- 
mended adjuvant radiation therapy because there was positive margin on histopathology.

\section{Conclusion}

Adenoid cystic carcinoma is an extremely rare condition with less than one case per year in our country. The symptoms are somewhat confusing and can lead to misdiagnosing and wrong treatment. Once the accurate diagnosis is made, treatment options are narrow and include surgery alone, radiation therapy, or a combination of both. Survival is almost the same for patients treated by surgery only and those treated by adjuvant radiation therapy but data on this are not satisfactory. The reason for that is the small number of cases and inadequate follow up. However, it is clear that all patients with positive resection margin need adjuvant radiation therapy. In these cases, oncologic approach is restricted by anatomic limitations and poses a therapeutic challenge. Individual approach to every patient is needed.

\section{References}

1. El Marjany M, Arsalane A, Sifat H, Andaloussi K, Oukabli M, Hadadi K, et al. Primary adenoid cystic carcinoma of the trachea: a report of two cases and literature review. Pan Afr Med J. 2014;19:32. http://dx.doi.org/10.11604/pamj.2014.19. 32.4878 .
2. Slobodnjak Z. Dušnik. In: Šoša T, editor. Kirurgija. Zagreb: Naklada Ljevak; 2007:637-40. (in Croatian)

3. Vladović-Relja T. Operativni pristupi i zahvati na traheji. In: Vladović-Relja T. Torakalna kirurgija. Zagreb: Medicinska naklada; 2014:598-632. (in Croatian)

4. Grillo HC. Tracheal tumors: surgical management. Ann Thorac Surg. 1978;26(2):112-25.

5. Shadmehr MB, Farzanegan R, Graili P, Javaherzadeh M, Arab $\mathrm{M}$, Pejhan S, et al. Primary major airway tumors; management and results. Eur J Cardiothorac Surg. 2011;39(5):749-54. http://dx.doi.org/10.1016/j.ejcts.2010.08.047.

6. Honings J, Gaissert HA, van der Heijden HF, Verhagen AF, Kaanders JH, Marres HA. Clinical aspects and treatment of primary tracheal malignancies. Acta Otolaryngol. 2010;130 (7):763-72. http://dx.doi.org/10.3109/00016480903403005.

7. Huo Z, Meng Y, Wu H, Shen J, Bi Y, Luo Y, et al. Adenoid cystic carcinoma of the tracheobronchial tree: clinicopathologic and immunohistochemical studies of 21 cases. Int J Clin Exp Pathol. 2014;7(11):7527-35.

8. Gaissert HA, Mark EJ. Tracheobronchial gland tumors. Cancer Control. 2006;13(4):286-94. http://dx.doi.org/10.1177/10 7327480601300406.

9. Kohno N, Tateno H, Kawaida M, Fukuda H. Primary adenoid cystic carcinoma of the trachea: a case report of a twelve-year survivor. Keio J Med. 1995;44(1):30-2.

10. Le Péchoux C, Baldeyrou P, Ferreira I, Mahé M. Thoracic adenoid cystic carcinomas. Cancer Radiother. 2005;9(6-7):358-61. (in French) http://dx.doi.org/10.1016/j.canrad.2005.07.010

11. Kanematsu T, Yohena T, Uehara T, Ushijima C, Asoh H, Yoshino I, et al. Treatment outcome of resected and nonresected primary adenoid cystic carcinoma of the lung. Ann Thorac Cardiovasc Surg. 2002;8(2):74-7.

Sažetak

\section{ADENOIDNI CISTIČNI KARCINOM DISTALNE TRAHEJE: PRIKAZ SLUČAJA}

\section{Ž. Djaković, Z. Janerski, V. Cesarec, Z. Slobodnjak i D. Stančić-Rokotor}

Primarni maligni tumori traheje su iznimno rijetki s incidencijom manjom od dva slučaja na milijun stanovnika u jednoj godini, a adenoidni cistični karcinom čini samo deset posto. Osamdeset posto svih tumora traheje je maligno. Dijagnoza se obično postavlja kasno, jer su početni simptomi slični astmi. Ponekad je klinička slika dramatična kada dođe do opstrukcije dišnog puta i potrebe za hitnom rekanalizacijom. Dijagnoza se potvrđuje kompjutorskom tomografijom prsišta ili magnetnom rezonancom. Definitivno liječenje je resekcija tumora sama ili uz adjuvantnu radioterapiju, ili radioterapija sama. Radikalna resekcija se postiže samo u oko polovice svih slučajeva zbog submukoznog rasta tumora i ograničene duljine resekcije traheje. Uloga adjuvantne radioterapije u slučajevima s negativnim resekcijskim rubom je nejasna, dok svi bolesnici s pozitivnim resekcijskim rubom imaju koristi od adjuvantne radioterapije. Prikazujemo slučaj 43-godišnjeg bolesnika s adenoidnim cističnim karcinomom distalnog dijela traheje koji je liječen bronhoskopskom rekanalizacijom i resekcijom traheje s terminoterminalnom anastomozom.

Ključne riječi: Karcinom, adenoidni cistični; Radioterapija, pomoćna; Trahealni tumori 